\title{
IMPLEMENTING PICTURE DICTATION TO IMPROVE SPEAKING ABILITY OF THE SECOND YEAR STUDENTS AT MA PESANTREN GUPPI SAMATA
}

\author{
Kasmi \\ Universitas Islam Negeri Alauddin Makassar \\ kasmi161001@gmail.com \\ Indah Fadhilah Rahman \\ Universitas Islam Negeri Alauddin Makassar \\ Indah.fadhilah@uin-alauddin.ac.id
}

\begin{abstract}
The objective of this research is to improve speaking ability by Implementing Picture Dictation of the Second Year Students (II B) at MA Pesantren GUPPI Samata Kabupaten Gowa. This research was classified as Classroom Action Research (CAR). It was conducted in two cycles, which was held three meetings in its every cycle. The subject of this research was the students of eleventh grade of MA Pesantren GUPPI Samata Kabupaten Gowa. They are XI B which consisted of 20 students with 10 boys and 10 girls. The data were quantitative obtained from tests (preliminary study test, first cycle test, and second cycle test) and observation guidelines. The result of this research showed that improvement of the students' speaking ability from the first cycle to the second cycle has improved. The mean score of vocabulary terms was $\mathbf{3 . 2 0}$ in the first cycle test and became $\mathbf{3 . 8 0}$ in the second cycle test. Besides that, the mean score of grammar in the first cycle was 3.45 became 3.95 in the second cycle. Then, pronunciation terms, the students score from first cycle to the second cycle was 3.20 became 3.65. Furthermore for the students' speaking accuracy and fluency, their score also increase from 3.40 became 3.70. Based on the data above, the researcher concludes that using picture dictation increased the speaking ability of the Second Year Students (II B) at MA Pesantren GUPPI Samata.
\end{abstract}

Keywords: Speaking, Picture Dictation, Second Year Students.

\section{A. BACKGROUND}

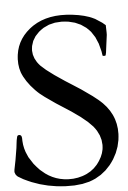

peaking is the most important skill to communicate and to understand each other. This is because speaking is a key to communicate as an interactive process of developing meaning that involves producing, receiving, and processing information. It shows we must be able to speak well therefore we can produce language to understand each other as a goal of speaking learning process especially in foreign language.

Most of people speak more than write in a daily life, but the other hand so many teachers of English ignore speaking and listening skill, the teachers spend the majority of class time on reading and writing skill in learning process. In the fact, Hymes (1972) in Richards and Rogers (2001: 158) stated that the goal of learning language is to communicate but English is not used for communication in their daily life. They are more focus on linguistic form or grammar. Thus, they do not have more chance and motivation to practice their speaking. As consequently, most of the students feel that speaking skill is difficult things to 


\section{Kasmi, Indah Fadhilah Rahman, Implementing Picture Dictation ...}

communicate because they do not have experience to apply it. Chomsky in Kaharuddin (2013: 1) stated that much of human language use was created from underlying knowledge of abstract rules drive from innate aspect of mind and human process experience through language. Without having experience, they become passive ones. In this case, teachers have to teach Speaking as students' experience in learning English.

Furthermore teach speaking skill in the class is not easy as imagined. Based on the researcher's observation at MA Pesantren GUPPI Samata Kabupaten Gowa Provinsi Sulawesi Selatan on September $20^{\text {th }} 2016$ where the researcher identified the problems of students' speaking as follow: there are some reasons why the students usually get some difficulties to speak in English. The first, the students did not like English class because the class was boring. The second, the students were lack of vocabulary and the students did not have basic in English to speak. So, they did not have knowledge of making a sentence. The third, the students were anxiety, low of confidence and motivation in expressing their ideas. Although, the students spoke, they always spoke in their mother tongue or they chose to be passive ones. The fourth, the class environment did not support them to speak English. Thus, the students ignore to improve their skills to speak in English. Therefore, practice is the most important to improve the students' speaking.

Based on the conditions, teachers have to come up with many kinds of ideas to provide the learning facilities as natural as possible. This is important because the goal of the language learning is to achieve communicative competence. The teacher should have a good and unique method to teach speaking, for example using games, picture or study out of the class. In this case, to solve the problems above the researcher will use Picture Dictation to improve students' speaking as method in teaching learning processes. According to Heath (n.d.: 58) said that Picture Dictation is an interesting way in English class. Its mean that there are some varieties way in the learning process which the students do some challenge activities like listen, draw, predict the picture etc.

Then, the most important is the students more interest learn by picture as method because it is not only interesting but also visual method that is effective to make the students be more active in the learning process. So, the researcher tries to apply it in speaking teaching through listening first. It is because the listening is related to speaking. Adding to Brown (2004: 140) said that from a pragmatic view of language performance, listening and speaking are almost always closely interrelated and Broughton, et al. (1988: 76) said that however good a student may be at listening and understanding, it need not follow that he will speak well. The 


\section{Volume 3, Number 02, December 2017}

teacher only uses the picture and the information of picture. In speaking process, the teacher only dictate the name of each picture in the paper and the students draw the picture, the next students describe it by speaking what they listen before. It can help the students to get the key idea of the information that are dictated. Drawing is one of interesting activity in teaching and learning process. It will make the students more enjoy, did not bored, and be enthusiastic in speaking teaching process. Moreover, picture is one of visual support in teaching process.

On the other hand, Rubin (2011) said that visual support can help the students to understand the text. In the picture dictation activity, the students draw their imagination of the information in the text that the teacher dictated. It will help the students to find out the key idea of the text. Furthermore, the picture helps the students to remember the information that they listen then the students describe it by speaking.

Therefore, by using picture dictation is believed to have direct influence on the speaking skills because when learning is fun, students can remember what they have learned. Then, based on the description above, the researcher would like to formulate the title: Implementing Picture Dictation to Improve Speaking Ability of the Second Year Students (II B) at MA Pesantren GUPPI Samata Kabupaten Gowa Provinsi Sulawesi Selatan.

\section{B. REVIEW OF RELATED LITERATURE}

\section{Previous of related findings}

Dwinalida (2013) conducted the result of the study that was aimed to answer or not using Picture Dictation can improve the Listening comprehension of the tenth grade students of SMA Islam Az-Zahra Palembang. The population of this study was the tenth grade students of SMA Islam Az-Zahra Palembang, in academic year 2013-2014. The sample was selected by using total sampling. The result of independent sample t-test showed that there was improvement in listening comprehension achievement of the students who were though through Picture Dictation.

Syahrir conducted a study about improving the students' speaking ability by using Biography in Picture at the second year of Islamic Boarding School MA As'adiyah Putra Pusat Sengkang, academic year 2013/2014. The subject of this research consisted of fifteen students. The instruments were test and observation guidelines. The researcher applied Classroom Action Research (CAR). It consisted of two cycles. Each cycle consisted of three meetings and four steps. The steps include plan, action, observation, and reflection. The result of the research showed that the students' achievement and performance from the first to the 


\section{Kasmi, Indah Fadhilah Rahman, Implementing Picture Dictation ...}

second cycle have improved highly. Based on the description above, the researcher conclude that Biography in Pictures increased the students speaking ability especially in producing Question at the second year of Islamic Boarding School MA As' Adiyah Putra Pusat Sengkang Significantly.

Khatimah (2014) conducted a study about the effectiveness of using picture word inductive model to improve students' vocabulary (a pre experimental research at Madrasah Aliyah (MA) Guppi Samata Kab. Gowa in academic year 2014/2015. In this research, the population is the first grade. The number of the population was 78 students. In taking the sample, Class X A was chosen by using cluster random sampling technique. Pre-experimental method was applied in this research with one group pre-test and post-test design. The instrument used to collect the data was vocabulary test. Based on the result of the research, the researcher suggest that Picture Word Inductive Model may be used as alternative media in teaching vocabulary because it can help students to think inductively, analyze and identify the picture automatically, In order that the students can understand and more interested in learning activity especially in learning English.

Mutakabbir (2014) conducted a study using narrating picture to improve the speaking ability of the second year student at SMP Negeri 1 Sinjai Selatan. The objective of the research is to reveal the effectiveness of using narrating picture technique in developing the second year students' speaking ability at SMP Negeri 1 Sinjai. Based on the finding and discussion of the research, the research drew a conclusion that the use of narrating picture is effective to improve the students' speaking ability in the second year student at SMP Negeri 1 Sinjai Selatan.

As the conclusion of researcher, the findings of some researchers above describe that using Picture generally and Picture Dictation especially in conducting materials in English can make students learn, achieve, and get the goals easily. Three of four researches above are same with this research because this research used Picture. However, all of the researches above have differences with this research. This research will use a picture dictation as the method in speaking teaching process. The students did not write words of dictation, but the students drew in dictation process. It helped the students to be more creative and try to find out the main idea or important information of dictation to describe the picture by speaking. 


\section{Volume 3, Number 02, December 2017}

\section{Some Pertinent Ideas}

a. Concept of speaking

Oxford Learner's Pocket Dictionary (2008: 426) speaking is talking to somebody about something, use your voice to say something, be able to use a language, make a speech to an audience. In short, the speaking skill is the ability to perform the linguistic knowledge in the actual communication. There are some definitions of speaking. one of definition is from Channey (1998: 13) who state that "speaking is the process of building and sharing meaning through the use of verbal and non-verbal symbols in variety of contexts".

Byrne (1991: 8) who said that, "speaking is a two way process between speaker and listener and involves the productive skill of speaking and the receptive skill of understanding."

Ann in Abdullah (2011: 111) said that speaking is a key to communication. Brown (2004: 140) said that speaking is a productive skill that can be directly and empirically observed, those observation are invariably colored by the accuracy and effectiveness of a testtaker's listening skill.

\section{b. Concept of Picture}

Hornby (1995) defines picture as a painting, drawing, sketch, etc. Picture gives students information which does not require translation. Picture can avoid long explanation in words which students would understand (collocate Online).

Drawing activity used as a means of teaching and learning has been believed to be very useful and facilitating. Through drawing, the students not only can learn language in an enjoyable way, but also can express themselves.

c. Concept of Dictation

Davis and Rinvolucri (1988: 1) said that in many case the teacher probably read you the text, dictated it, and then read it a third time so you could check through. To many people this, and nothing else, is dictation. Then, David (n.d.: 5) said dictation is another testing device that retains some of its former popularity in certain areas. Dictation is undoubtedly a useful pedagogical device (if used in moderation) with beginning and lowintermediate-level learners of a foreign language, and the responses that such students make to dictations will certainly tell the teacher something about their phonological, grammatical, and lexical weaknesses.

Harmer (2009: 91) said that dictation is probably the best-known activity for intensive listening, but it fell out of fashion soon after the arrival of the communicative approach. Many teachers realize, however, that dictation has great benefits as an activity type. Davis and 


\section{Kasmi, Indah Fadhilah Rahman, Implementing Picture Dictation ...}

Rinvolucri list ten good reasons for using it in class, including the fact that students are active during and after the dictation, that it is good for mixed ability (because it is entirely receptive, requiring no output from the student) and large classes, and provides access to interesting text. Another benefit is that it is a multi-skill activity, potentially, involving listening, writing, reading and speaking. It is a great way to focus the attention of over animated students or daydreamers at the back of the class. Furthermore, dictation is a very flexible activity, with numerous variations which we will look at in this section.

\section{d. Concept of Picture Dictation}

Heath (n.d: 58) stated that Picture Dictations are a quick, amusing and interesting way of doing a number of useful things in the English class. First, they test listening comprehension. Second, they provide a useful way of revising certain prepositions of place. Lastly, they provide a good basis for a guided composition, getting the pupils to describe the picture using some of the language you dictated.

e. Advantages and Disadvantages of Picture Dictation

Based on Nicola Meldrum and Lindsay Clandfield there are some advantages and disadvantages of using picture dictation in class activity. The advantages of Picture Dictation are: (1) Students have the constant attention of the teacher so they can listen to and speak more English than they might in a group situation; (2) Students can contribute to classes more and feel part of the learning process by bringing material like books, songs, articles from local newspapers to class; (3) Their strengths and weaknesses are addressed more consistently and fully without the competition of other students for the teacher's time; (4) They can become better learners through learner training with their teacher; (5) There are less time constraints so they can go at their own pace and not feel pressured by the progress of other students. Then, the disadvantages of Picture Dictation are: (1) There is a similar potential for exhaustion as they too can be in constant interaction in an unnatural way with the teacher; (2) It can be difficult to measure progress without other students to compare with and the possible lack of a syllabus; (3) There can be a lack of individual study time. They might not have the same "sink in time" as they would have in a group; (4) The lesson format can become monotonous if a teacher lacks the confidence to experiment with change of pace and type of activity. They might assume a student would not be open to activities such as dictation, songs, moving around the class, chants, drilling, etc.

f. Procedures of Teaching Speaking Ability through Picture Dictation 
Teaching speaking through picture dictation can be applied as following: (1) The researcher will begin the class by giving some explanations related to the material that will be given; (2) Next, the class will be dictated the components of item in the picture; (3) Then, the students draw what they are dictated by teachers; (4) Next every students will express or explain it by speaking; (5) Finally, the student that can express or explain it by speaking will get a score as the criteria.

\section{RESEARCH METHOD}

In this research researcher used Kemmis and Taggart model of Classroom Action Research. Kemmis and Taggart described the model or the procedures of Classroom Action Research into four tests. They are; (1) plan (identify the problem), (2) action (collect the data), (3) observation (analyze and interpret data) and evaluation (4) reflection (develop an action). The relations among them was called a cycle. It meant that a cycle consists of plan, action, observation, evaluation, and reflection.

\section{RESULT AND DISCUSSION}

\section{The Result of the Preliminary Study, First cycle test and Second cycle test}

The mean score of the preliminary study was vocabulary (1.10), grammar (1.15), Pronunciation (1.45), and accuracy and fluency (1.25). Four of them were inadequate. These are the students' speaking score of preliminary study test:

Table 1

The First Score of Students' test (Preliminary Study)

\begin{tabular}{|c|c|c|c|}
\hline \multirow{5}{*}{} & Scores $(\mathrm{s})$ & Frequencies $(\mathrm{f})$ & Percentages $(\%)$ \\
\cline { 2 - 4 } & 5 & 0 & 0 \\
\cline { 2 - 4 } & 4 & 0 & 0 \\
\cline { 2 - 4 } & 3 & 0 & 0 \\
\cline { 2 - 4 } & 2 & 3 & 15 \\
\cline { 2 - 4 } & 1 & 16 & 80 \\
\hline Mean Score : 1.10 & 0 & 1 & 5 \\
\hline \multirow{5}{*}{ Grammar } & & 20 & 100 \\
\cline { 2 - 4 } & Scores $(\mathrm{s})$ & Frequencies $(\mathrm{f})$ & Percentages $(\%)$ \\
\cline { 2 - 4 } & 5 & 0 & 0 \\
\cline { 2 - 4 } & 4 & 0 & 0 \\
\cline { 2 - 4 } & 3 & 0 & 20 \\
\cline { 2 - 4 } & 2 & 4 & 5 \\
\hline
\end{tabular}


Kasmi, Indah Fadhilah Rahman, Implementing Picture Dictation ...

\begin{tabular}{|c|c|c|c|}
\hline Mean Score : 1.15 & & 20 & 100 \\
\hline \multirow{7}{*}{ Pronunciation } & Scores (s) & Frequencies (f) & Percentages $(\%)$ \\
\hline & 5 & 0 & 0 \\
\hline & 4 & 0 & 0 \\
\hline & 3 & 0 & 0 \\
\hline & 2 & 10 & 50 \\
\hline & 1 & 9 & 45 \\
\hline & 0 & 1 & 5 \\
\hline Mean Score : 1.45 & & 20 & 100 \\
\hline \multirow{7}{*}{$\begin{array}{l}\text { Accuracy and } \\
\text { fluency }\end{array}$} & Scores $(\mathrm{s})$ & Frequencies (f) & Percentages $(\%)$ \\
\hline & 5 & 0 & 0 \\
\hline & 4 & 0 & 0 \\
\hline & 3 & 0 & 0 \\
\hline & 2 & 6 & 30 \\
\hline & 1 & 13 & 65 \\
\hline & 0 & 1 & 5 \\
\hline Mean Score $: 1.25$ & & 20 & 100 \\
\hline
\end{tabular}

Table 1 above showed us the students' score of the first test (preliminary study). The data indicated the students' score in speaking. It showed that the students' score were very poor and all the students had problems in speaking. Therefore, the teacher tried to apply an Interesting Strategy in his class to overcome the students' problem and improve the students' speaking ability.

\section{The Result of the First Cycle Test}

This is following result of students' test in the first cycle:

Table 2

The Students' Score of First Cycle Test

\begin{tabular}{|c|c|c|c|}
\hline \multirow{4}{*}{ Vocabulary } & Scores $(\mathrm{s})$ & Frequencies (f) & Percentages (\%) \\
\cline { 2 - 4 } & 5 & 0 & 0 \\
\cline { 2 - 4 } & 4 & 7 & 35 \\
\cline { 2 - 4 } & 3 & 10 & 50 \\
\cline { 2 - 4 } & 2 & 3 & 15 \\
\cline { 2 - 4 } & 1 & 0 & 0 \\
\hline Mean Score :3.20 & 0 & 0 & 0 \\
\hline \multirow{5}{*}{ Grammar } & & 20 & 100 \\
\cline { 2 - 4 } & Scores (s) & Frequencies (f) & Percentages $(\%)$ \\
\cline { 2 - 4 } & 5 & 0 & 0 \\
\cline { 2 - 4 } & 4 & 13 & 15 \\
\cline { 2 - 4 } & 3 & 3 & 20 \\
\cline { 2 - 4 } & 2 & 4 & 0 \\
\cline { 2 - 4 } & 1 & 0 & 0 \\
\hline
\end{tabular}


Volume 3, Number 02, December 2017

\begin{tabular}{|c|c|c|c|}
\hline Mean Score : 3.45 & & 20 & 100 \\
\hline \multirow{4}{*}{ Pronunciation } & Scores (s) & Frequencies (f) & Percentages (\%) \\
\cline { 2 - 4 } & 5 & 0 & 0 \\
\cline { 2 - 4 } & 4 & 9 & 45 \\
\cline { 2 - 4 } & 3 & 6 & 30 \\
\cline { 2 - 4 } & 2 & 5 & 25 \\
\cline { 2 - 4 } & 1 & 0 & 0 \\
\hline Mean Score :3.20 & 0 & 0 & 0 \\
\hline Accuracy and & & 20 & 100 \\
\cline { 2 - 4 } fluency & Scores (s) & Frequencies (f) & Percentages $(\%)$ \\
\cline { 2 - 4 } & 5 & 0 & 0 \\
\cline { 2 - 4 } & 4 & 11 & 55 \\
\cline { 2 - 4 } & 3 & 6 & 30 \\
\cline { 2 - 4 } & 2 & 3 & 0 \\
\cline { 2 - 4 } & 1 & 0 & 100 \\
\hline Mean Score : 3.40 & 0 & 20 & 0 \\
\hline
\end{tabular}

Table 2 above described the students' speaking achievement (vocabulary, grammar, pronunciation, fluency and accuracy) of the first action-test in the first cycle. This kind of data showed us that after giving students' action classes "Picture Dictation" in the previous two meetings of the first class, their conversation grades became quite better even a bit for each meeting. Firstly, the mean score of the students' vocabulary of the first test before giving action was only 1.10. That score comes up to 3.20 in the first cycle test. In addition, almost students achieved score 1 (16 (80\%) students), hardly achieved score 2 (3 (15\%) students only), score $3(0(0 \%)$ student), score 4 (0 (0\%) student), score $5(0(0 \%)$ student $)$ and score 0 (1 (5\%) student because did not come) in the first test before giving the action. Overall, none of them got excellent at all. Those all compared scores indicated that the students' accuracy and fluency in the first cycle test was better rather than their prior score in the preliminary study test. From a number of comparison explained above, the researcher took a first conclusion that a few of students' problems including vocabulary, grammar, pronunciation, accuracy and fluency in doing speaking activity could be decreased by using Picture Dictation.

Finally, based on the table above, the percentage of students' speaking score with eight students passed the first cycle test was $\mathbf{4 0 \%}$. It means that there were $40 \%$ students of the class could pass the criteria of minimum successful or KKM. The students speaking score had improved but the improvement did not reach the target of research which was $65 \%$ of students could pass the criteria of minimum successful (KKM). To achieve the target of the research, there were still needed $25 \%$ or around five students who could pass the criteria of 
minimum successful (KKM).

\section{The Result of the Second Cycle Test}

This is following result of students' test in the second cycle:

Table 3

The Students' Score of Second Cycle Test

\begin{tabular}{|c|c|c|c|}
\hline \multirow{7}{*}{ Vocabulary } & Scores $(s)$ & Frequencies (f) & Percentages $(\%)$ \\
\hline & 5 & 3 & 15 \\
\hline & 4 & 10 & 50 \\
\hline & 3 & 7 & 35 \\
\hline & 2 & 0 & 0 \\
\hline & 1 & 0 & 0 \\
\hline & 0 & 0 & 0 \\
\hline Mean Score : $\mathbf{3 . 8 0}$ & & 20 & 100 \\
\hline \multirow{7}{*}{ Grammar } & Scores $(\mathrm{s})$ & Frequencies (f) & Percentages $(\%)$ \\
\hline & 5 & 3 & 15 \\
\hline & 4 & 13 & 65 \\
\hline & 3 & 4 & 20 \\
\hline & 2 & 0 & 0 \\
\hline & 1 & 0 & 0 \\
\hline & 0 & 0 & 0 \\
\hline Mean Score : 3.95 & & 20 & 100 \\
\hline \multirow{7}{*}{ Pronunciation } & Scores $(s)$ & Frequencies (f) & Percentages $(\%)$ \\
\hline & 5 & 0 & 0 \\
\hline & 4 & 14 & 70 \\
\hline & 3 & 5 & 25 \\
\hline & 2 & 1 & 5 \\
\hline & 1 & 0 & 0 \\
\hline & 0 & 0 & 0 \\
\hline Mean Score : $\mathbf{3 . 6 5}$ & & 20 & 100 \\
\hline \multirow{7}{*}{$\begin{array}{c}\text { Accuracy and } \\
\text { fluency }\end{array}$} & Scores $(\mathrm{s})$ & Frequencies (f) & Percentages $(\%)$ \\
\hline & 5 & 1 & 5 \\
\hline & 4 & 13 & 65 \\
\hline & 3 & 5 & 25 \\
\hline & 2 & 1 & 5 \\
\hline & 1 & 0 & 0 \\
\hline & 0 & 0 & 0 \\
\hline Mean Score : $\mathbf{3 . 7 0}$ & & 20 & 100 \\
\hline
\end{tabular}




\section{Volume 3, Number 02, December 2017}

Table 3 above shows that the students' grades of the second cycle test. It indicates that the students' second cycle test increased better than their first cycle test. The mean score of students' vocabulary in the first cycle test was $\mathbf{3 . 2 0}$ whereas they get increase in the second cycle test with mean score 3.80. Besides that, the mean score of their previous grammar was 3.45 then it became better in the second cycle test with 3.95. In addition, the mean score of the students previous pronunciation was $\mathbf{3 . 2 0}$ then it increase become $\mathbf{3 . 6 5}$ in the second cycle test. Furthermore, their accuracy and fluency of the first cycle test rose from $\mathbf{3 . 4 0}$ to $\mathbf{3 . 7 0}$ in the second cycle test.

Moreover, the highest score of students' vocabulary in the first cycle test was 4 which gained by 7 students whereas the highest score in the second cycle test was 5 which was obtained by 3 students. In similar words, the score 4 is the highest score of the students' grammar that gained by 13 students in the first cycle test whereas that score 5 is the highest score although only gained by 3 students in the second cycle test. Then, the score 4 of the pronunciation was gotten by 9 students only in the first cycle test whereas the highest score in the second test is 4 also but the students were getting score 4 increase that obtained by 14 students. In addition, the score 4 of the students' accuracy and fluency gained by 11 students in the first cycle test whereas that score could be gained by 12 students but there is one student gained score five in the second test. As a matter of excellent comprehension grade, there are some students could gain score 5 in some aspects in the second cycle test. Those all data showing that there was an improvement of students ability from their vocabulary, grammar, pronunciation, accuracy and fluency of each. Finally, based on the table above, the percentage of students' speaking score with fifteen students passed the second cycle test was 75\%. It means that the class could pass the criteria of minimum successful (KKM). Overall, those quite improvements indicating the students' speaking ability could be recovered and enhanced by using picture dictation.

\section{The Results of the Observation in the First Cycle and the Second Cycle}

For clear information about the improvements, see the following table:

\section{Table 4}

Comparison the Results of the Observation between the First Cycle (C1) and the Second Cycle (C2)

\begin{tabular}{|l|l|c|c|c|}
\hline \multirow{2}{*}{ Aspects } & \multicolumn{1}{|c|}{ Indicators } & \multicolumn{2}{|c|}{ Percentage } & Change \\
\cline { 3 - 5 } & & C1 & C2 & \\
\hline $\begin{array}{l}\text { Learning } \\
\text { Activities }\end{array}$ & $\begin{array}{l}\text { Doing their assignments based on the } \\
\text { teachers' instruction. }\end{array}$ & 70 & 85 & +15 \\
\hline
\end{tabular}


Kasmi, Indah Fadhilah Rahman, Implementing Picture Dictation ...

\begin{tabular}{|c|c|c|c|c|}
\hline & $\begin{array}{l}\text { Asking question to their teacher if there } \\
\text { is an instruction which is not clear. }\end{array}$ & 65 & 75 & +10 \\
\hline & $\begin{array}{l}\text { Giving comments and suggestions } \\
\text { about their friends' job. }\end{array}$ & 65 & 75 & +10 \\
\hline & $\begin{array}{l}\text { Presenting their discussion result } \\
\text { without being appointed by the teacher. }\end{array}$ & 55 & 60 & +5 \\
\hline & $\begin{array}{l}\text { Discussing and working together with } \\
\text { their friends in doing their assignments. }\end{array}$ & 70 & 80 & +10 \\
\hline & $\begin{array}{l}\text { Doing assignments from their teacher } \\
\text { well. }\end{array}$ & 65 & 75 & +10 \\
\hline \multirow[b]{3}{*}{ Creativities } & $\begin{array}{l}\text { Showing their curiosity by asking } \\
\text { question to their teacher and friends. }\end{array}$ & 65 & 70 & +5 \\
\hline & Exploring their ideas. & 50 & 65 & +15 \\
\hline & $\begin{array}{l}\text { Thinking and are not hopeless for } \\
\text { looking for answer using books or } \\
\text { asking to their friends. }\end{array}$ & 70 & 75 & +5 \\
\hline \multirow{2}{*}{$\begin{array}{l}\text { Feeling of } \\
\text { happiness }\end{array}$} & Looking happy in learning process. & 65 & 85 & +20 \\
\hline & $\begin{array}{l}\text { Not feeling sleepy during the teaching } \\
\text { and learning process. }\end{array}$ & 65 & 80 & +15 \\
\hline \multirow{3}{*}{ Interaction } & Discussing with their teacher. & 65 & 75 & +10 \\
\hline & Discussing with their friends. & 70 & 85 & +15 \\
\hline & Working together with their friends. & 70 & 85 & +15 \\
\hline \multicolumn{2}{|l|}{ Mean Score } & 65 & 76 & +11 \\
\hline
\end{tabular}

Based on the table above, there were some improvements for the students' activities. It made the researcher and the collaborators very happy because the improvements were increase even though they did not really satisfy. The table above showed that most of the indicators for each aspect increased.

Besides, there were still some indicators that did not perform as accepted. There were many factors that caused that. They were:

1) The students were less time presenting their presentation in front of the class because of limited time

2) There some students were shy asking question to their teacher

3) There were many students did not have enough time to explore their ideas.

\section{Discussion}

To make this discussion clear, the researcher would like to explain in parts; improving the students' speaking ability by using Picture Dictation. From the four indicators that have analyzed, namely: vocabulary, grammar, pronunciation, accuracy and fluency, and also the students learning activities, creativity, feeling of happiness, motivation and interaction each other showed that picture dictation was very effective in improving students' speaking ability.

This research related of previous findings, Dwinalida (2013) conducted the result of the study that was aimed to answer or not using Picture Dictation can improve the Listening comprehension of the tenth grade students of SMA Islam Az-Zahra Palembang. The 206 


\section{Volume 3, Number 02, December 2017}

population of this study was the tenth grade students of SMA Islam Az-Zahra Palembang, in academic year 2013-2014. The result of independent sample t-test showed that there was improvement in listening comprehension achievement of the students who were though through Picture Dictation. On the other hand, the researcher was actually optimistic in this teaching technique early. The cause of his optimist based on Douglas Brown (2004: 140) who said that from a pragmatic view of language performance, listening and speaking are almost always closely interrelated. Picture dictation considered has complied with the statement above.

Case (2011: 1) stated that a picture dictation makes the students easily to understand the text by find out the key idea. It was appropriate with the study of Rubin (2011) that visual support can help the students to understand a text. In the picture dictation, they drew their imagination of the information in the text.

The main point in this study was to improve the students' speaking ability and overcome the students' problems in speaking. It was happened because the student achievements and performances improve from the first cycle to the second cycle. Even though, it still need some stabilization, but it has to be stopped because it has limited time and all students have passed in this lesson and get good scores. Moreover, passion and motivation that have owned by the students can be the great factors of development of their achievement. Therefore, if there is someone wants to continue this research in the next time, it will be great and the researcher will really appreciate it.

In the first cycle, the speaking ability of the students for some criteria, they are vocabulary, grammar, pronunciation and accuracy and fluency showed that their ability in each criterion after testing and observing was so far from goodness event most students were lack of speaking. The causes of their lack were students low of confident and motivation, vocabulary and one problem that almost student had about pronunciation and structure of language.

To solve the problems, the researcher prepared all students' need to face them in the second cycle, such as; a new topic, give them vocabulary related topic that would be used. Then, the researcher taught them how to pronounce it, give them motivation and give them assignment to effort them to speak. The result of the students' achievement in the second cycle in vocabulary, grammar, pronunciation and accuracy and fluency, after testing and observing showed great improvement. It also can be seen mean score test and observation in the first cycle and in second cycle. Moreover, it is not impossible that the students will get achievement more if it is seen from their potential which base on their enthusiasm in learning that was showed while researching. Actually, among all achievement that the students showed, the most increased was their enthusiasm.

On the other hand, there are strength and weakness by using picture dictation. The strength of using this method was very attractive in getting the students' attention because of 


\section{Kasmi, Indah Fadhilah Rahman, Implementing Picture Dictation ...}

using the several activities make the students felt no bored while studying during the classroom and can help develop all four language skills in an integrated way, then the students easily speak to describe the picture according to their idea based on the picture.

The weakness of this method was there many that must be prepared by the teacher before come to the classroom that needed long time to teach in the classroom because we have to dictate first before let them speak and we have to prepared interesting picture.

\section{E. CONCLUSION AND SUGGESTION}

\section{Conclusion}

Relating to the research findings and discussion in the previous chapter, the conclusions are presented in the following statements:

The data was gained from test and observation within both first cycle and second cycle and also from observation guidelines showed that the students' speaking ability after being taught by picture dictation had significantly improved. Their spoken English became better in the end section of this research. It proved enough the effects as well as the benefits of picture dictation in enhancing the students' speaking ability.

A number of problems faced by the students while describing the event was happened on the picture dictation showed at the beginning of research were the students' speaking ability found that they did mispronunciation, they were low of confident and motivation, vocabulary and one problem that almost student had about pronunciation and structure of language. As a matter of hope, the second cycle test indicated that their previous problems in speaking decreased even did not recovered all perfectly. Picture dictation was able to decrease the students' errors in doing speaking English and could also encourage the students' motivation and their feeling into the class. This Class Action Research proved enough that students' speaking ability could be improved by using picture dictation.

\section{Suggestion}

The researcher would like to give a suggestion to the teachers of English that this method was very useful to teach speaking or even practicing speaking inside the classroom however there were many method to be used in teaching learning process, but using picture dictation was only an alternative method of teaching speaking that could overcome your problem while teaching English especially for teaching speaking such as; students were difficult in expressing their idea and students less motivated. This method was better for you. Besides that, this method had strength and weakness. For more detail, the researcher would explain as follows;

The strength of using this method was very attractive in getting the students' attention because of using the several activities make the students felt no bored while studying during the classroom and can help develop all four language skills in an integrated way. 
The weakness of this method was there many that must be prepared by the teacher before come to the classroom that needed long time to teach in the classroom because we have to dictate first before let them speak and we have to prepared interesting picture.

\section{REFERENCES}

Abdullah, Wahidah. (2011) Code Mixing in Speaking. Makassar: Alauddin University Press.

Arikunto, S. (2013), et al. Penelitian Tindakan Kelas. Jakarta: PT. Bumi Aksara,

Abubakar, M. S. (2015). Improving the Second Year Students' Speaking Ability through Project Based Learning (PBL) at MTsN Model Makassar. ETERNAL (English, Teaching, Learning, and Research Journal), 1(2), 216-228.

Asik, N., \& others. (2016). The Effectiveness Of Using Visual Aids Integrated Communicative Language Teaching Method In Improving The Students'speaking Ability At The Second Grade Of Sman 1 Pinrang. ETERNAL (English, Teaching, Learning, and Research Journal), 2(2), 167-182.

Bahar, Andi Kaharuddin. (2013). The Communicative competence-Based: English Language Teaching. Yogyakarta: TrustMedia.

Broughton, Geoffrey, et al.(1998). Teaching English as a Foreign Language. Second edition. USA: Routledge \&Kagen Paul.

Brown, H. Douglas.(2004). Language Assesment: Principles and Calssroom Practice. USA: Longman.

Byrne, D. Focus on the Classroom. (1998). Retrieved 21 April 2016, access from http://www.amazon.com/Focus-Classroom-SelectedDonnByrne/dp/ 0906149878.

Case, A. (2017). Drawing on Drawing Games Part Two-Picture Dictation. Retrieved 20 February 2017, access from http://www.tefl.net/alexcase/tefl/tefl-games/picture-dictation/

Channey, A. L. \& Burk.T.L.(1998). Teaching Oral Communication in Grades K.8. Boston..

Davis, Paul \& Mario Rinvolucri.(1998). Dictation: New methods, new Possibilities. New York: Cambridge University.

Dwinalida, Khairunnisa. (2013). "Teaching Listening Comprehension Through Picture Dictation to the Tenth Grade Students of SMA Islam Az-Zahrah Palembang". Thesis. Palembang: Faculty of Teacher Training and Education of Sriwijaya University.

Ferlazzo, Larry \& Katie Hull Sypnieski.(2012) The ESL/ELL Teacher's Survival Guide: Ready-toUse Strategies, Tools, and Activities for Teaching English Language Learners of All Levels. San Francisco: Jossey-Bass.

Gay. L. R. et al.(2006). Educational Research Competences for Analysis and Application. Eight Edition; Colombus: Pearson Merrill Prentice Hall.

Harmer, Jeremy.(2010). How to Teach English. New edition; England: Longman.

.... (2009). How to Teach Listening. England: Longman.

Harris, David P. (n.d.). Testing English as a Second Language. New Delhi: Tata McGraw-Hill.

Heath, R. Picture dictations. Singapore: Institute of Education, (n.d.). Retrieved 20 Maret 2016, access from: http://www.google.com/url?sa=t\&rct=j\&q= 


\section{Kasmi, Indah Fadhilah Rahman, Implementing Picture Dictation ...}

\&esrc $=$ s\&source $=$ web\&cd $=1 \& \mathrm{cad}=$ rja\&ved $=0 \mathrm{CDMQFjAA \& url}=\mathrm{http} \% 3 \mathrm{~A} \% 2 \mathrm{~F} \% 2$ Frepository.nie.edu.sg $\% 2 \mathrm{Fj}$ spui $\% 2 \mathrm{Fbitstream} \% 2 \mathrm{~F} 10497 \% 2 \mathrm{~F} 2836 \% 2 \mathrm{~F} 1 \% 2 \mathrm{FT}$

Hornby, A. S. (1995). Oxford advanced learner's dictionary of current English. New York, NY: Oxford University Press.

Huddleston, Rodney. (1988). English Grammar: an outline. New York: Cambridge University Press.

McNiff J \& Whitehead J. (2002). Action Research: Principle and Practice. London: Routledge Falmer.

Nasir, S. H. (2015). To Improve Students'interpersonal Communication Skills By Means Of

Cooperative Learning Ioc At Piba Program Of Uin Alauddin Makassar. ETERNAL

(English, Teaching, Learning, and Research Journal), 1(1), 84-97.

Nurpahmi, S. (2015). Improving Listening Skill By Activating Students'prior Knowledge.

ETERNAL (English, Teaching, Learning, and Research Journal), 1(1), 28-38.

Nurpahmi, S. (2013). An Introduction to English for Specific Purposes. Makassar: Alauddin University Press.

Nurpahmi, S. (2014). English for Specific Purposes: An Integrated Approach. Makassar: Alauddin University Press.

Oxford University. (2008). Oxford Learner's Pocket Dictionary. New York: Oxford University Press.

Rahmah, F., \& St Nurjannah, Y. T. (2016). The Use of Scaffolding Talk Technique To Improve The Second Grade Students Speaking Skill At Mts Madani Paopao Gowa. ETERNAL (English, Teaching, Learning, and Research Journal), 2(2), 252-268.

Richards. J. C. and Rogers. T.S.(2001) Approaches and Methods in Language Teaching. Cambridge: Cambridge University Press.

Rubin, J. (2011). "A review of second language listening comprehension research", The Modern Language Journal. Retrieved 20 Maret 2016, Access from:

http:/ $/$ www.google.com/url?sa $=t \& r c t=j \& q=\& e s r c=$ s\&source $=$ web\&cd $=1 \& c a d=r j$ a\&ved $=0 \mathrm{CDgQFiAA \& url}=\mathrm{http} \% 3 \mathrm{~A} \% 2 \mathrm{~F} \% 2 \mathrm{Fjan}$.ucc.nau.edu $\% 2 \mathrm{~F} \sim$ jgc $\% 2 \mathrm{~F} 512 \% 2 \mathrm{~F}$ listeningrubin.pdf\&ei $=$ rfxtUfjbOMGMrQffsYDoBw\&usg=AFQjCNH739PrdsFJoz d7QCsXRf FtpMZ 2A\&sig2=NbjwrOP3NIbCDtnZCHIHWA.

Rusdi, S. Y. F. (2015). Improving the students Speaking Ability by Using Thematic Materials (A Classroom Action Research To The First Year Students of MTSN. Model makassar). ETERNAL (English, Teaching, Learning, and Research Journal), 1(2), 257-269.

Tiro, Muhammad Arif.(2008). Dasar-Dasar Statistika. Makassar: Andira Publisher, 2008.

Ur, P. \& Andrew Wright. (1995). Five-Minutes Activities: A resource book of short activities. New York: Cambridge University Press.

(1996). A course in Language Teaching. Cambridge. Cambridge University Press.

Widdowson. H. G. \& Quirk, R.(1985). English in The World: Teaching and Learning the Language and Literatures. Cambridge: Cambridge University Press. 